\title{
GENERALIZATIONS OF CYCLIC REFINEMENTS OF JENSEN'S INEQUALITY BY LIDSTONE'S POLYNOMIAL WITH APPLICATIONS IN INFORMATION THEORY
}

\author{
NAsir Mehmood, SaAd Ihsan Butt, Đilda PeČArić And Josip PEČArić
}

\begin{abstract}
Jensen's inequality plays pivotal role in attaining divergence between probability distributions. Shannon, Relative and Zipf-Mandelbrot entropies have ample applications in many applied sciences, especially in information theory, biology, economics, etc. In the present paper, we have obtained new generalizations of cyclic refinements of Jensen's inequality using different new Green functions by employing Lidstone's polynomial. As an application of our obtained results we have given new entropic bounds. Also, we have established the connections between Shannon and Relative entropy with Zipf-Mandelbrot entropy.
\end{abstract}

Mathematics subject classification (2010): 26A51, 26D15, 26E60, 94A17, 94A15.

Keywords and phrases: $2 n$-convex function, Lidstone's polynomial, new Green functions, divergence functional, Shannon entropy, relative entropy, Zipf-Mandelbrot entropy.

\section{REFERENCES}

[1] R. P. Agarwal And P. J. Y. Wong, Error Inequalities in Polynomial Interpolation and their Applications, Kluwer Academic Publishers, Dordrecht, (1993).

[2] G. Aras-Gazić, V. Culjak, J. PeČArić ANd A. Vukelić, Generalization of Jensen's inequality by Lidstone's polynomial and related results, Math. Inequal. Appl. 16(4) (2013), 1243-1267.

[3] I. BRnetić, K. A. KhAN AND J. PeČARIĆ, Refinement of Jensen's inequality with applications to cyclic mixed symmetric means and Cauchy means, J. Math. Inequal. 9(4) (2015), 1309-1321.

[4] S. I. Butt, K. A. Khan AND J. PeČARIĆ, Popoviciu type inequalities via Green function and generalized Montgomery identity, Math. Inequal. Appl. 18(4) (2015), 1519-1538.

[5] S. I. Butt, J. PeČARIĆ And A. Vukelić, Generalization of Popoviciu type inequalities Via Fink's identity, Mediterr. J. Math. 13(4) (2016), 1495-1511.

[6] S. I. ButT AND J. PeČARIĆ, Popoviciu's inequality for n-convex functions, Lap Lambert Academic Publishing ISBN: 978-3-659-81905-6 (2016).

[7] A. Chao, L. Jost. T.C. Hsieh, K.H. Ma And Sherwin W.B. ET AL., Expected Shannon Entropy and Shannon Differentiation between Subpopulations for Neutral Genes under the Finite Island Model, PLOS ONE. 10(6) (2015), 1-24.

[8] P. Cerone And S. S. DRAGOmiR, Some new Ostrowski-type bounds for the Čebyšev functional and applications, J. Math. Inequal. 8(1) (2014), 159-170.

[9] S. S. DRAGOMIR, Upper and Lower Bounds for Csiszar's f-Divergence in Terms of the KullbackLeibder Distance and Applications, Inequalities for the Csiszar's f-divergence in Information Theory, (2000), http://rgmia.vu.edu.au/monographs/ciszar.htm.

[10] L. HoRvÁTH, Inequalities corresponding to the classical Jensen's inequality, J. Math. Inequal. 3(2) (2009), 189-200.

[11] L. Horváth , Đ. PeČAriĆ AND J. PeČARIĆ, Estimations of $f$ - and Rényi Divergences by Using a Cyclic Refinement of the Jensen's Inequality, Bull. Malays. Math. Sci. Soc., (2017), https://doi.org/10.1007/s40840-017-0526-4.

[12] L. Horváth , K. A. Khan And J. PeČARIĆ, Combinatorial improvements of Jensen's inequality, Monographs in Inequalities 8, Element, Zagreb, (2014). 
[13] Horváth L., K. A. KHAn AND J. PeČARIĆ, Cyclic refinements of the discrete and integral form of Jensen's inequality with applications, Analysis, Munich. 36(4) (2016), 253-263.

[14] I. CSISZÁR, Information-type measures of diference of probability distributions and indirect observations, Studia Sci Math Hungar. 2 (1967), 299-318.

[15] J. JAKŠEtic, Đ. PeČARIĆ And J. PeČARIĆ, Some properties of Zipf-Mandelbrot law and Hurwitz $\zeta$-function, Math. Inequal. Appl. 21(2) (2018), 575-584.

[16] JAKŠETIC J. AND PeČARIĆ J., Exponential convexity method, J. Convex. Anal. 20(1) (2013), 181197.

[17] M. A. KhAN, Đ. PeČARIĆ And J. PeČARIĆ, Bounds for Shannon and Zipf-mandelbrot entropies, Mathematical Method in Applied Sciences. 40( 18) (2017), 7316-7322.

[18] M. A. Khan, Đ. PeČArić And J. PeČArić, On Zipf-Mandelbrot entropy, Computational and Applied Mathematics. 346 (2019) 192-204.

[19] S. Kullback, Information Theory and Statistics, J. Wiley, New York. (1959).

[20] A. LESNE, Shannon entropy: a rigorous notion at the crossroads between probability, information theory, dynamical systems and statistical physics, Mathematical Structures in Computer Science. (2014) 24(3), 63 pages. doi:10.1017/S0960129512000783.

[21] N. Mehmood, R. P. Agarwal, S. I. Butt And J. PeČarić, New generalizations of Popoviciutype inequalities via new Green's functions and Montgomery identity, J.Inequal. Appl. (2017), 2017:108.

[22] J. Pečarić, F. Proschan and Y. L. Tong, Convex functions, Partial Orderings and Statistical Applications, Academic Press, New York, (1992).

[23] J. PeČArić And J. Perić, Improvement of the Giaccardi and the Petrović inequality and related Stolarsky type means, An. Univ. Craiova Ser. Mat. Inform. 39(1) (2012), 65-75.

[24] J. PEČARIĆ, M. PRALJAK AND A. WitKOWSKI, Linear operator inequality for $n$-convex functions at a point, Math. Inequal. Appl. 18 (2015), 1201-1217.

[25] C. E. Shannon, A mathematical theory of communication, Bull. Sept. Tech. J. 27 (1948), 370-423 and 623-656.

[26] S. T. PIANTADOSI, Zipf's word frequency law in natural language: a critical review and future directions, Psychonomic bulletin and review. (2014) 21(5), 1112-1130.

[27] Z. K. SilagadZe, Citations and the Zipf-Mandelbrot Law, Complex Systems. (1997) (11), 487-499.

[28] E. Wedrows Ka, Application of Kullback-Leibler Relative Entropy for Studies on the Divergence of Household Expenditures Structures, Olsztyn Economic Journal. (2011) 6, 133-142.

[29] D. V. WidDER, Completely convex function and Lidstone series, Trans. Am. Math. Soc. 51 (1942), 387-398. 